\title{
Studies on the effects of growing substrates and physical factors in sweet pepper forcing in context with the generation of calcium deficiency symptoms
}

\author{
Lantos, F., ${ }^{1}$ Pék, Z., ${ }^{2}$ Monostori, T. ${ }^{1}$ \& Helyes, L. ${ }^{2}$ \\ ${ }^{1}$ Faculty of Agriculture, University of Szeged, Hódmezövásárhely \\ ${ }^{2}$ Institute of Horticultural Technology, Faculty of Agriculture and Environment, Szent István University, Gödöllö
}

Summary: In the publications available for us, exact levels of physical factors and those of the growing technology determining $\mathrm{Ca}^{2+}$ deficiency are rarely detailed. Although the influencing role of the various environmental factors (humidity, light, temperature) is known, we had only little information about their exact values which could be presented for the growing practice. Sweet pepper varieties of the same type grown in various substrates responded to the environmental factors in different ways. Our results revealed that increasing temperature of the root zone had the most significant effect on the incidence of $\mathrm{Ca}^{2+}$-deficient fruits. Their amount, however, gave different results depending on the growing substrate. In forced sweet pepper grown in soil the proportion of $\mathrm{Ca}^{2+}-$ deficient fruits were significantly lower compared to the plants grown on rockwool. Fruits derived from forcing on perlite, in container were damaged the least by the blossom end rot deficiency symptoms. Our experimental results and technological suggestions are based on measurement results of three years.

Key words: calcium deficiency, root zone temperature, pepper (Capsicum annuum L.), blossom end rot (BER)

\section{Introduction}

In Hungary on the Southern Great Plain the largest part of the vegetable forcing area, 2000-2200 ha, was covered by sweet pepper giving a yield of 150-175 thousand tons in the last years (Tégla et al., 2006). From the economical point of view sweet pepper is one of the most important vegetable crops of the country. Therefore studies on the safety of production are a current task because nutrient content of the culture media as well as the production technology have a significant impact on the chemical composition and quality of the yield. Krug et al. (1972) observed that in spite of the overwhelming calcium supply, insufficient $\mathrm{Ca}^{2+}$ uptake caused by high humidity resulted in $\mathrm{Ca}^{2+}$ deficiency in intensive forcing. Besides macro-elements essential microand meso-elements can also have a significant role in the biological development of the plants (Griss, 1944; Terbe et al., 2005). Their absence can even lead to an irreversible damage of the fruit (Takahashi et al., 1999). In pepper forcing $\mathrm{Ca}^{2+}$ deficiency symptoms cause severe fruit damages in the extremely warm periods. On the fruit apex the so-called blossom-end rot can be observed (Terbe et al., 2005). Calcium has a wide range of physiological roles. It has a great importance in cell division and in cell metabolism, but its role can be observed also in the formation of the root mass. Plants can take up calcium only in the form of $\mathrm{Ca}^{2+}$-ion through the leaves or the roots. Interacting with the $B$-indoleacetic acid it has a role in the differentiation of plant cells, in cell elongation and in the stabilization of the middle lamella of the cell wall (Bergmann, 1960; Szalai, 1974). According to our current knowledge, $\mathrm{Ca}^{2+}$ deficiency is the only one among nutrient supply disorders (deficiency symptoms, poisoning symptoms etc.) which generates spots on the fruits of Solanaceae species therefore in sweet pepper (Capsicum annuum L.) as well (Terbe \& Szabó, 2003). A great number of researchers stated that the blossom-end rot occurring on pepper fruits originated from the lack of $\mathrm{Ca}^{2+}$. The apex of the fruit is continuously built up from the youngest cells showing an increased demand for calcium. In the case of its absence the young cell will be irreversibly damaged. Therefore, rotting spots can be observed always near the fruit apex (Zatykó, 1993). Bussler (1963) stated that $\mathrm{Ca}^{2+}$-deficiency symptoms always occur on the youngest as well as still differentiating organs. According to Terbe et al. (2005), during this process the fruit epidermis ruptures then, always near the blossom end, grayish-brown lesions occur which soon dry out. These spots indicate lime deficiency. Through the lesions pathogens can get into the plant tissues and cause further damages (Glits \& Folk, 2000; Reményi et al., 2003) (Figure 1). In the course of production calcium deficiency of the soil can be generated by a drastic reduction in $\mathrm{pH}$, the soil acidity $(>3)$. On the other hand, high concentration of $\mathrm{H}^{+}, \mathrm{K}^{+}, \mathrm{Na}^{+}, \mathrm{Mn}^{2+}, \mathrm{Al}^{3+} \cdot \mathrm{Mg}^{2+}, \mathrm{NH} 4-$ ions in the soil can generate antagonistic effect. In this case the absorption of $\mathrm{Ca}^{2+}$ - ions is impeded by the ions (elements) being present in high concentration (Wojciechowski et al., 1969). At the occurrence of the deficiency symptoms, however, we can already talk about the actual calcium 
deficiency of the plants. In the plants $\mathrm{Ca}_{2+}-$ ions are transported in the xylem by the transpiration flow relatively easy but normally they are not transferred into the phloem. Due to its difficult transport in the phloem, the reverse transport of $\mathrm{Ca}^{2+}-$ ion from leaves into stem and root or from the older leaves into the younger, growing parts is negligible (Bergmann, 1979). The level of calcium demand varies from plant to plant and there can be differences among varieties. If a plant, for any reason, does not take up the available nutrients, starvation symptoms occur on its fruits (Chapmann, 1966). An excess in $\mathrm{Ca}^{2+}$ does not occur directly in plants, while it leads to limechlorosis if occurring in soil (Bergmann, 1979). Perlite is a volcanic rock of relatively high water content which can be found in nature as well. Its most important property is that it absorbs moisture and desorbs it only in dry conditions. It swells as the effect of moisture uptake. Expanded perlite is an environmentally friendly natural rock of white color, high porosity and granular structure which has a high heat insulation ability $(\lambda=0.045$ $-0.070 \mathrm{~W} / \mathrm{mK}$ ). Typical composition of perlite is $70-75 \%$ silicium-dioxide $\mathrm{SiO}_{2}, 12-15 \%$ aluminium-oxide $\mathrm{Al}_{2} \mathrm{O}_{3}$, $3-4 \%$ sodium-oxide $\mathrm{Na}_{2} \mathrm{O}, 3-5 \%$ potassium-oxide $\mathrm{K}_{2} \mathrm{O}$, $0.5-2 \%$ ferric-oxide $\mathrm{Fe}_{2} \mathrm{O}_{3}, 0.2-0.7 \%$ magnesium-oxide $\mathrm{MgO}, 0.5-1.5 \%$ calcium-oxide $\mathrm{CaO}$. Saturated with water it is poured around the roots. Adhered to roots it can supply them with water in the case of high temperature. It regulates water regime of the plant and improves soil climate (Bolen, 2003).

\section{Materials and methods}

Our measurements and observations were performed in the summer forcing period of three years $(2007,2008$, and 2009) in Szentes in the Alsoréti Horticulture Farm of the DABIC Nonprofit Ltd. Forcing was performed in two neighboring plastic tunnel greenhouses of $100 \mathrm{~m}$ length, $9 \mathrm{~m}$ width and $900 \mathrm{~m}^{2}$ floor area. Tunnels can be ventilated through windows on the Southern and Northern end as well as three windows on the sides. Examinations were performed with sweet pepper grown in soil, perlite and rockwool. Prior to forcing a soil analysis was performed with the following result: $\mathrm{pH}: 7.6, \mathrm{CaCO}_{3}$ content: $1.0 \%$, humus: $2.9 \%, \mathrm{NO}_{3}$ $\mathrm{NO}_{2}-\mathrm{N}: 10 \mathrm{mg} / \mathrm{kg}, \mathrm{P}_{2} \mathrm{O}_{5}: 300 \mathrm{mg} / \mathrm{kg}, \mathrm{K}_{2} \mathrm{O}: 550 \mathrm{mg} / \mathrm{kg}$. Before planting in the spring of 2008 the soil was improved by turkey litter.

From planting to the first fruit set an average of $1.8 \mathrm{EC}$, in the subsequent period to the picking period of August an average concentration of 2.0 EC Poli-feed complex nutrient solutions was used. Water and nutrients were supplied through a drip irrigation system. In the case of pepper forcing on rockwool the nutrient solution composition recommended by the Grodan Company was applied. The sweet pepper variety Emese $F_{1}$ was used in both experiments. In the year 2009 a control measurement was performed in Kiskunmajsa, on the horticulture farm of the Kirsche Ltd. The pepper variety Cecey $F_{1}$ grown in perlite, in containers was examined here on an area of $3000 \mathrm{~m}^{2}$. Plastic containers of 121 volume have been used. During forcing the Poli-feed complex fertilizer recommended for pepper forcing was used.

In the experiments we determined the outdoor temperature, the indoor temperature under the plastic tunnel, the air humidity, as well as the pepper root-zone temperature regime in the growing substrates (soil, rockwool, perlite). Proportion of the $\mathrm{Ca}^{2+}$ - deficient fruits was determined at each picking. In the course of the forcing period 10 picking dates were examined and evaluated.

\section{Main properties of the hybrids applied in the experiments:}

Emese $\mathbf{F}_{1}$ : Continuously growing forcing hybrid with upright, white, sweet big fruits of elongated conic shape. It is weak growing, when tied up it can be cultivated the most effectively with one thread pruning. It sets very well even in poor light conditions. Its fruit big, thick fleshed, in economic maturity the weight is $90-120 \mathrm{~g}$ (Ledóné, 2007).

Cecey $\mathbf{F}_{1}$ : Continuously growing, forcing hybrid with pendant, white, sweet big fruits of elongated conic shape. It is of medium growth, when tied up it can be cultivated the most effectively with one thread pruning. It is not sensitive to 
lack of light and it is resistant against tobacco mosaic virus (TMV). Its fruit is thick fleshed, in economic maturity the weight is $90-120 \mathrm{~g}$ (ZKI, Kecskemét).

\section{Results}

Figure 1 shows microscopic section of a healthy and that of a $\mathrm{Ca}^{2+-}$ deficient fruit. The latter one clearly shows the silvery mycelia of ovary moulding disease (Botrytis cinerea) (thin arrow) developing as secondary-infection after penetrating the tissues damaged due to $\mathrm{Ca}^{2+-}$ deficiency.

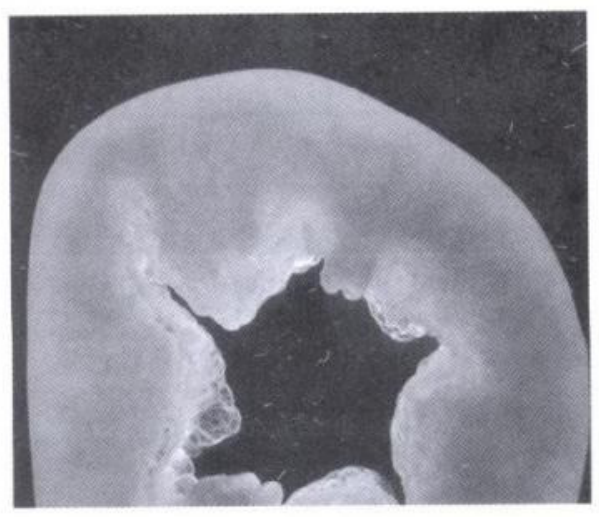

a) Transverse section of a healthy fruit

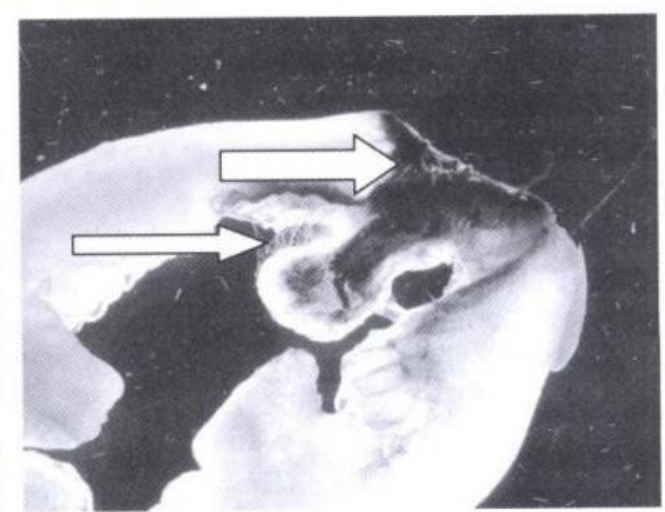

b) Tissue necrosis caused by $\mathrm{Ca}^{2+-}$ deficiency (thick arrow) and

Botrytis cinerea mycelia (thin arrow)
$17-23{ }^{\circ} \mathrm{C}$ which is nearly optimal for sweet pepper. In contrast, as the climate control of the plastic tunnel could not be solved, the temperature in the root zone was $28-29^{\circ} \mathrm{C}$ in July and August which already inhibited proper root functions (nutrient and water uptake). The year 2009 showed a little difference compared to the previous two because in the course of the 10 harvests the proportion of $\mathrm{Ca}^{2+}$ - deficient fruits significantly decreased from $15 \%$ to $2 \%$. Figure 3 shows the connections of product of the multiplication of soil and air temperature on rockwool. Data of the figure clearly show the close significant connection between the amount of $\mathrm{Ca}^{2+}$ - deficient fruits and the product of the multiplication of the two temperatures. In the rockwool block of $100 \times 150 \times 65 \mathrm{~mm}$ as well as in the rockwool mat the proper root mass could not formed on the high temperature thus the weaker root system is unable to take up $\mathrm{Ca}^{2+}$ - ion of necessary amount (Figure 4). In the rockwool block of geometrically determined form and size the root is able to grow downwards only, growing toward the sides is restricted. This causes problems in the formation of the normal tassel-like root system and in the function of the root hairs. The mechanism of nutrient uptake of root hairs is influenced at a critical extent also by the temperature above $22{ }^{\circ} \mathrm{C}$ in the root zone.

At pepper grown in rockwool it

\section{- Pepper forcing on rockwool}

In the critical periods examined, 8 . June -22 . August 2007, 18. June - 22. August 2008 and 7. May - 24. August 2009 , the average values of lowest and highest humidity were $86 \%$ and $92 \%$, respectively. The temperature of the nutrient solution was $20-22{ }^{\circ} \mathrm{C}$. Raschel net was used for shadowing in 2007 from 25. May, in 2008 from 20. May, in 2009 from 5. May to the end of the growing period. In the days before the picking on 23. June 2009 the nutrient delivery tube became clogged by the $\mathrm{CaCO}_{3}$ fertilizer. In the system $\mathrm{CaCO}_{3}$ dissolves poorly in water therefore in soilless cultures the application of $\mathrm{Ca}\left(\mathrm{NO}_{3}\right)_{2}$ is advised. In the course of unstopping clogged drains the plant population became slightly weaker and a significant mildew (Leveillula taurica Arn.) infection occurred. By the end of July the population restored to health but the exaggerated physical factors resulted in a significant number of damaged fruits.

Figure 2. shows the proportion of $\mathrm{Ca}^{2+}$-deficient fruits exhibiting blossom end rot in sweet pepper grown on rockwool during the three years of examination. In the years 2007 and 2008 in the course of the growing period the proportion of $\mathrm{Ca}^{2+}$-deficient fruits continuously increased from harvest to harvest. This can be explained by the changes of root-zone temperature. In 2007, in May and June the root zone temperature measured in the rockwool was between ${ }^{\circ} \mathrm{C}$ and humidity rising above $86 \%$ resulted in a significant increase in the amount of calcium-deficient fruits. The mean temperature of the nutrient solution was $20-22{ }^{\circ} \mathrm{C}$ in the summer thus it could not either cool down the plant through the root zone.

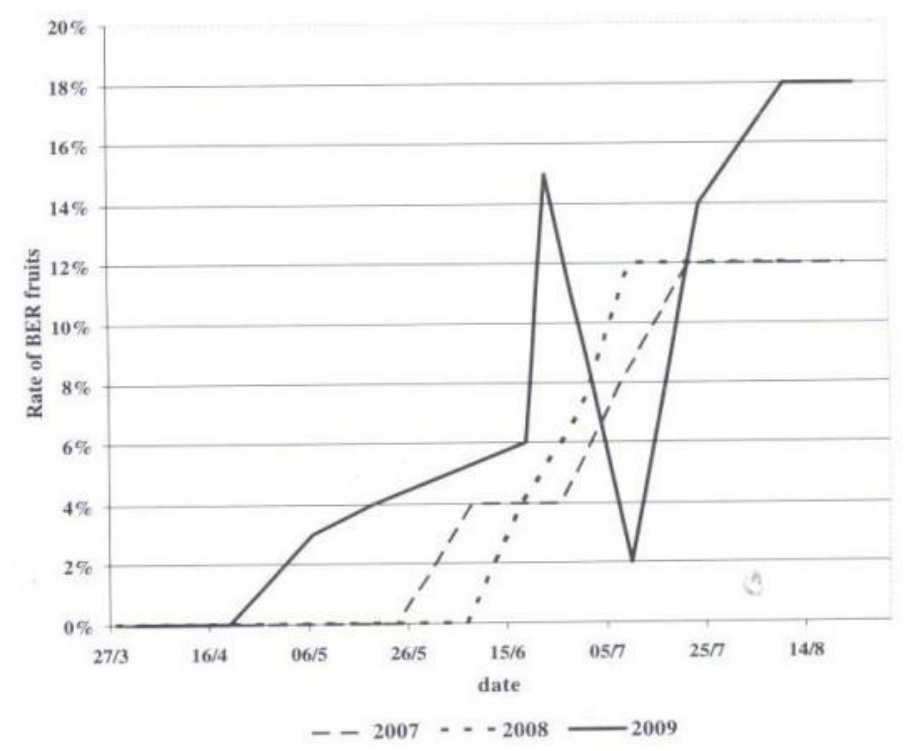

Figure 2. Yield losses caused by calcium-deficiency in sweet pepper grown on rockwool, 2007-2009 could be observed that root zone temperature rising above 22 


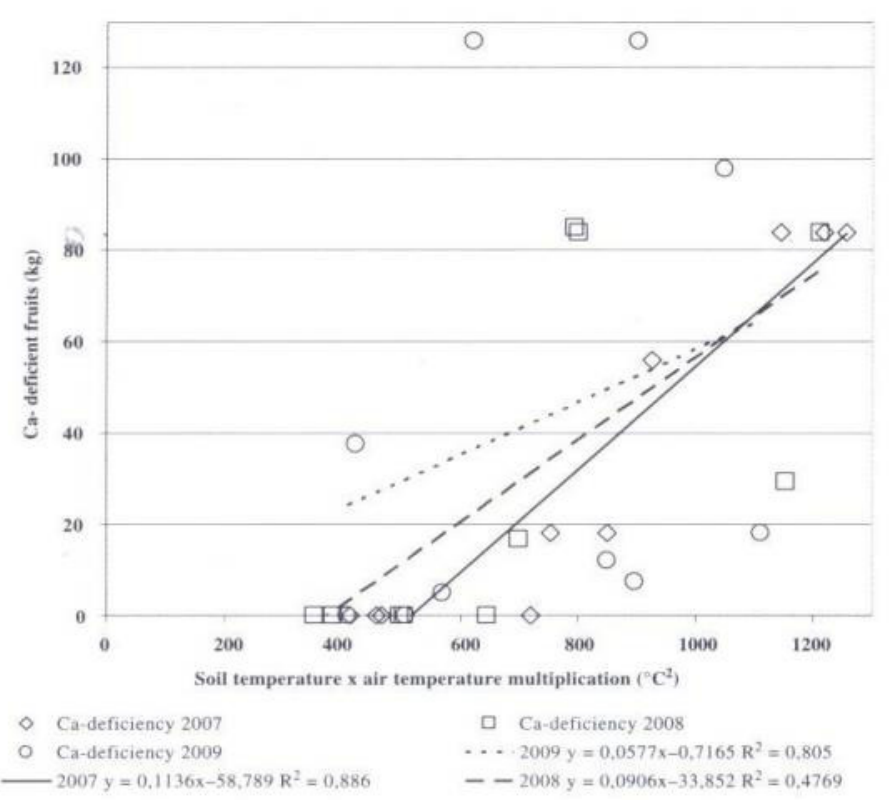

Figure 3. Correlation between soil temperature $\mathrm{x}$ air temperature multiplication and the amount of $\mathrm{Ca}^{2+}$ - deficient fruits on rockwool, together with the regression equations, in the three years of the experiments $(n=10)$

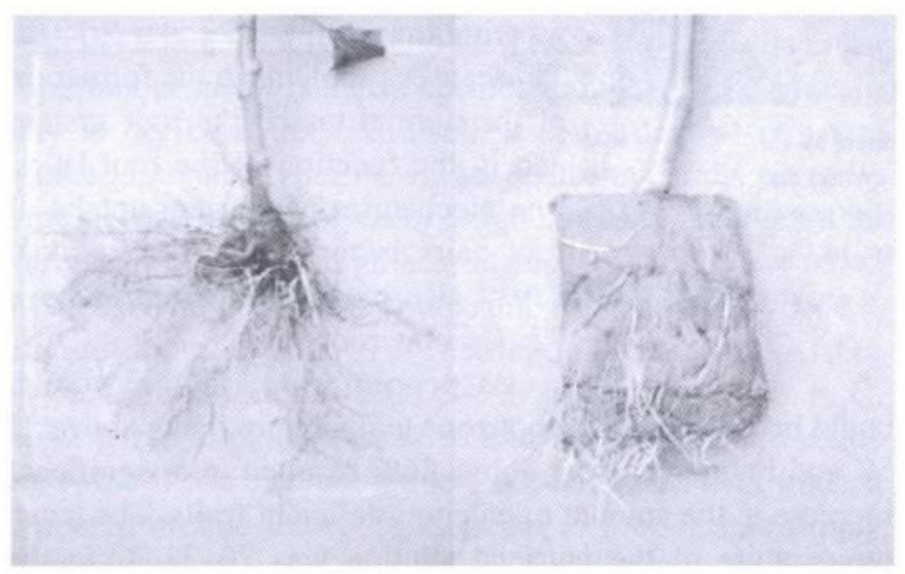

a) root mass in soil

b) root mass in rockwool

Figure 4. Development of the root mass in soil (a) and in rockwool (b)

\section{- Pepper forcing in soil}

In the critical periods examined, 8. June - 22. August 2007, 18. June -22 . August 2008 and 7. May - 24. August 2009, the average values of lowest and highest humidity were $86 \%$ and $92 \%$, respectively. In the course of growing soil loosening was performed in the population in the first week of July. It was followed by irrigation with water of $14{ }^{\circ} \mathrm{C}$ which cooled down the root zone below $20^{\circ} \mathrm{C}$. This is the critical temperature of $\mathrm{Ca}^{2+}-$ ion uptake determined by Dodd $(2000)$ in field production of pepper thus the proportion of $\mathrm{Ca}^{2+}-$ deficient fruits decreased. In the period, however, when loosening has not been performed, soil became more compact and the temperature of the root zone rose above $22^{\circ} \mathrm{C}$. This way, $\mathrm{Ca}^{2+}$ - ion uptake was not optimal which resulted in an increased number of $\mathrm{Ca}^{2+}$ - deficient fruits (Figure 5). In soils of looser structure the development of a proper root mass is not hampered unlike in the case of pepper grown in rockwool.

In the course of forcing in soil, a significant correlation between the product of the multiplication of soil temperature

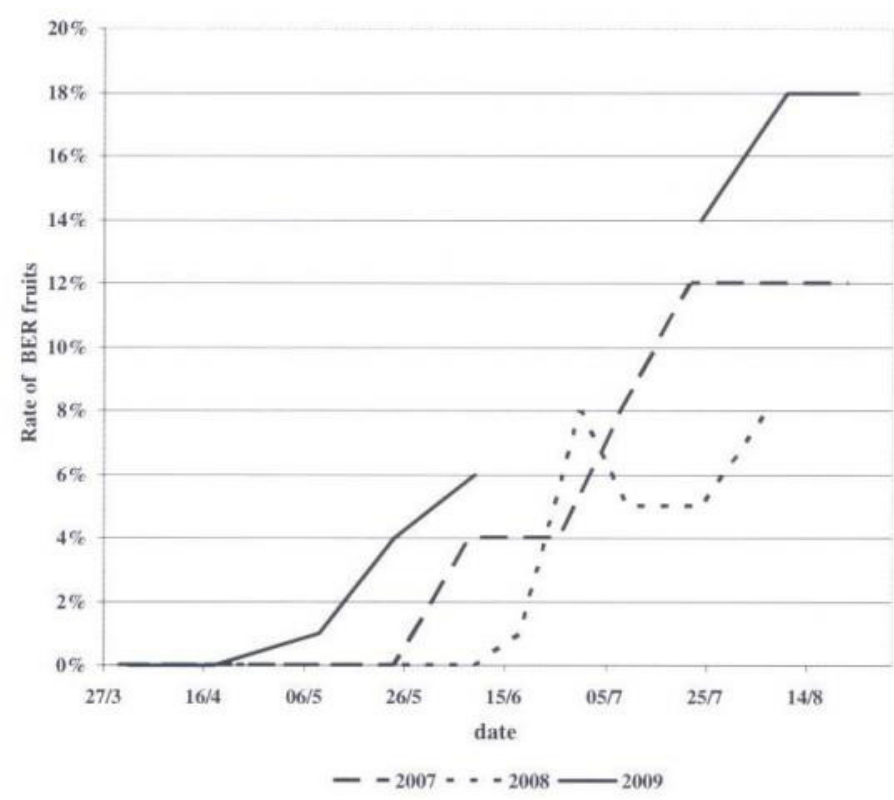

Figure 5. Yield losses caused by calcium-deficiency in sweet pepper forced in soil, 2007-2009

$\mathrm{x}$ air temperature and the amount of $\mathrm{Ca}^{2+}$ - deficient fruits $\left(\mathrm{R}^{2}=0.8\right)$ could be found in 2007 only (Figure 6 ).

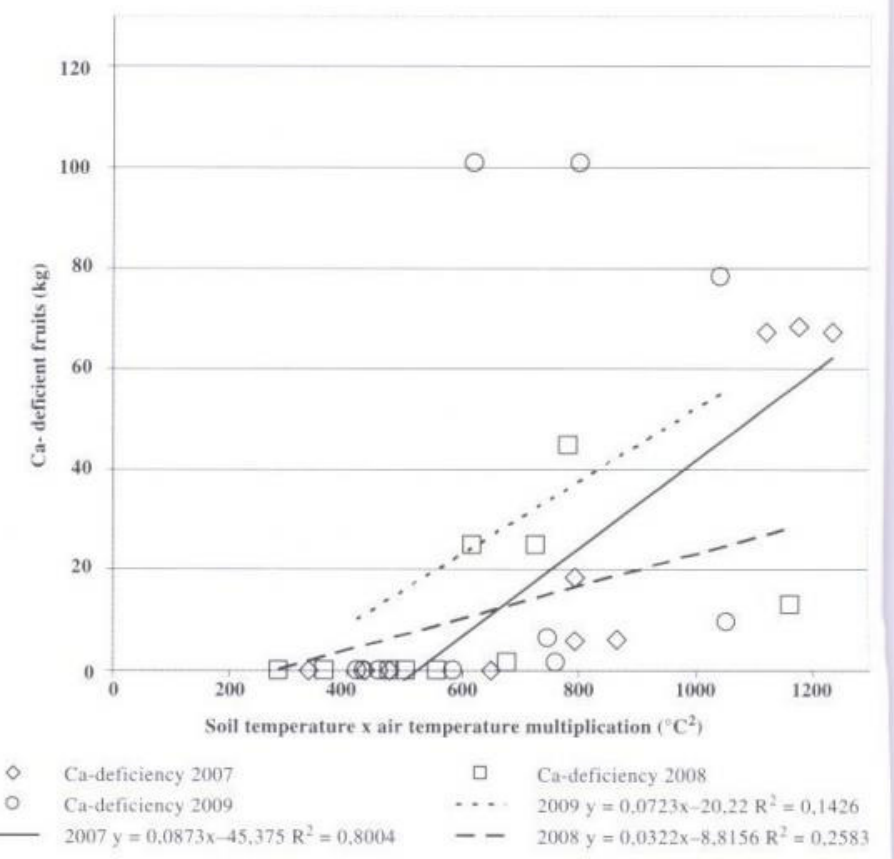

Figure 6. Correlation between the soil temperature $\mathrm{x}$ air temperature multiplication and the amount of $\mathrm{Ca} 2+-$ deficient fruits in soil, together with the linear regression equations, in the three years of the experiments $(n=10)$

\section{- Pepper forcing in perlite}

In the examined period between 5 . June -7 . September 2009 the lowest humidity was $70 \%$, the highest average $86 \%$. The average yield harvested between June and August was $2400 \mathrm{~kg}$. The percentage of BER fruits was $7 \%$ only. In the previous period of spring, in May $1200 \mathrm{~kg}$ pepper was harvested from the producing area of $3000 \mathrm{~m}^{2}$. In this case calcium-deficient fruits have not been found. 
The plastic tunnel was protected against UV-B irradiation by shadowing dye of white color from 15. June 2009. The plastic tunnel was covered by double-layer material with cold air circulating between the layers. The temperature of the nutrient solution did not rise above $16^{\circ} \mathrm{C}$. In the case of pepper grown in container humidity was not let rise above $86 \%$. Except for some days, the temperature of the root zone could be successfully kept below $20{ }^{\circ} \mathrm{C}$. This was achieved by an automatic, computerregulated system. In the course of forcing the amount of fruits exhibiting blossom end rot was far below the level of economic loss. Greenleaf and Adams (1969) revealed that blossom end rot is a genetically regulated variety trait depending on $\mathrm{Ca}^{2+}$. metabolism, which is in relation with the resistance of the plant. Therefore, we used TMV (tobacco mosaic virus) resistant pepper as control in the experiments on container growing.

Table 2. Examination of yield losses of pepper grown in perlite, in container in 2009

\begin{tabular}{|l|c|c|c|c|}
\hline $\begin{array}{l}\text { Picking } \\
\text { dates }\end{array}$ & $\begin{array}{c}\text { Outdoor } \\
\text { temperature } \\
{ }^{\circ}\end{array}$ & $\begin{array}{c}\text { Indoor } \\
\text { temperature } \\
\mathbf{C}\end{array}$ & $\begin{array}{c}\text { Temperature } \\
\text { of the root } \\
\text { zone }{ }^{\circ} \mathbf{C}\end{array}$ & $\begin{array}{c}\text { Proportion } \\
\text { of } \mathbf{C a}^{2+}- \\
\text { deficient } \\
\text { fruits (\%) }\end{array}$ \\
\hline 29. May & 12.5 & 18 & 16.5 & 0 \\
\hline 5. June & 19 & 21 & 17 & 0 \\
\hline 19. June & 30 & 28 & 20.2 & 10 \\
\hline 28. June & 20 & 28 & 20 & 0 \\
\hline 10. July & 25 & 28 & 20 & 0 \\
\hline 28. July & 24 & 33 & 20 & 0 \\
\hline 17. August & 30 & 32 & 25 & 4 \\
\hline 26. August & 30 & 33 & 23 & 0 \\
\hline 7. September & 22 & 28 & 20 & 0 \\
\hline
\end{tabular}

\section{Conclusions}

It can be concluded that to fulfill the $\mathrm{Ca}^{2+}$ requirement of the plant not only the $\mathrm{Ca}^{2+}$ level of the growing substrate should contain the necessary amount, while its absorbance is influenced also by other physical and biological factors. At the evolving of calcium deficiency of pepper fruits the temperature above $20^{\circ} \mathrm{C}$ measured for a long time in the root zone, humidity above $86 \%$, the poor root mass, the variety and its hardiness play a decisive role in influencing the absorbing capacity of the root system. In our experiments it was confirmed that water supplying ability of perlite as well as soil of loose structure and good water supply offers better cooling for the root system of pepper, thus root activity and the transpiration is not inhibited in the $\mathrm{Ca}^{2+}$ uptake process. The ventilation of the rockwool block is inhibited by the nylon wrapping glued around it and by the colonies of algae grown on its surface. Based on our results we revealed that temperature above $22^{\circ} \mathrm{C}$ in the root zone already inhibits $\mathrm{Ca}^{2+}-$ uptake and this applies to each growing substrate. Conditions of $\mathrm{Ca}^{2+}$ uptake and assimilation can be regulated by shadowing the growing estate, by the regulation of temperature and humidity, by the proper choice of variety if a side root system of proper mass and strength being characteristic for pepper has been developed.

\section{Acknowledgements}

The study was partly supported by TECH-09-A3-20090230, USOK2009 project.

\section{References}

Bussler, W. (1963): Die Entwicklung von Calcium-Mangelsymptomen. Z. Pflanzenernaehr Dueng. Bodenkunde. pp. 53-58-100.

Bergmann, W. (1960): Auftreten, Erkennen und Verhüten von Nahrstoff bei Kulturpflanzen. VEB. Deutscher Landwirtschaftsverlag, Berlin. Handschrift.

Bergmann, W. (1979): Termesztett növények táplálkozási zavarainak elöfordulása és mérése. Mezőgazdasági Kiadó, Budapest. 21-24.

Bolen, P. W. (2003): PERLITE. Geological Survey Minerals Yearbook USA.

Chapmann, H.D. (1966): Diagnostic criteria for plants and soils. Univ. of California, Div, of Agric. Sci., Riverside

Dodd, I. C. (2000): The influence of supra optimal root-zone temperatures on growth and stomatal conductance in Capsicum annuum L. Jurnal of Experiment Botany, Vol. 51. No. 343 pp. $239-248 \mathrm{p}$.

Glits, M. \& Folk, Gy. (2000): Élettelen, nem fertỏzö kórokok in: Kertészeti növénykórtan. Mezögazda Kiadó, Budapest. pp. 30.

Griss, E. (1944): Nouvelles experiences sur l'action des composés ferrugineux soluble, appliques e la vegetation, et specialement au traitament de la chlorosees, et de la débilité des plantes. Compt. Rend. Acad. Sci., Paris. 19. 1118-1119 p.

Greenleaf, W.H. \& Adams, F. (1969): Genetische Kontrolle der Blütenendfaule bei Tomaten über den Ca- Metabolismus. Amer. Soc. Hort. Sci., pp. 248-250

Krug, H. Wiebe, H. \& Jungk, A. (1972): Calciummangel an Blumenkohl unter Konstanten Klimabedingungen. Z. Pflanzenernaehr Bodenkunde, 113 pp. 213-226.

Ledóné, D. H. (2007): Étkezési paprikák összehasonlitó fajtakisérletei tavaszi és öszi hajtatásban. DABIC Kht. Szentes. 7 p.

Reményi, M.L. Szabó, Zs. \& Terbe, I. (2003): Az étkezési paprikafajták mészhiánybetegségeinek szövettani vonatkozásai. Kertgazdaság, 35. (4): pp. 9-12

Szalai I. (1974): Növényélettan I. Tankönyvkiadó, Budapest, 392 p. Takahashi, A. Camacho, P. Lechleiter, J.D. \& Herman, B. (1999): Measurements of intracellular calcium. Physiol. Rev. 79. pp. 1089-1125

Terbe, I. \& Szabó, Zs. (2003): A paprika csúcsrothadásos betegségét kiváltó okok megszüntetése és megelözése. Kertgazdaság, 35. (1): pp.100-104.

Terbe, I. Hodossi, S. \& Kovács, A. (2005): Zöldségtermesztés termesztöberendezésekben. Mezögazda Kiadó, Budapest. 88 p.

Tégla, Zs. Deme, P. \& Balogh, Zs. (2006): A paprikahajtatás gazdaságossága. Kulcskérdés az energia. Kertészet és Szölészet, 55. (7): $6-7 \mathrm{p}$.

Wojciechowski, J., Knaflewski, M. \& Borys, M.W. (1969): Verthaltnisses und des Stickstoffspiegels auf die Blütenfaule der Tomate. Phytopathol Z. 64. pp. 312-320.

Zatykó, L. (1993): Paprika. Mezőgazda Kiadó, Budapest 174 p. 